\title{
In Situ Activation of Human Erythrocyte Prolidase: Potential for Enzyme Replacement Therapy in Prolidase Deficiency
}

\author{
PETER HECHTMAN, ANDREA RICHTER, NATALIE CORMAN, AND YI-MUN LEONG \\ Centre for Human Genetics, Department of Biology, McGill University [P.H.] and MRC Human Genetics Group, \\ Montreal Children's Hospital [P.H., A.R.], Montreal, Quebec, Canada, H3H IP3
}

\begin{abstract}
Deficiency of prolidase is frequently associated with skin lesions and mental retardation. Biochemically, the condition is marked by iminodipeptiduria. We have investigated the feasibility of using donor erythrocytes to replace the deficient enzyme. Prolidase occurs in erythrocytes in an inactive form. If erythrocytes are incubated overnight at $37^{\circ} \mathrm{C}$ in the presence of $1 \mathrm{mM} \mathrm{MnCl}_{2}$, the intracellular $\mathrm{Mn}^{++}$concentration increases from 0.014 to $2.04 \mu \mathrm{g} / \mathrm{ml}$. As a consequence, the activity of prolidase in hemolysates increases to $159 \mu \mathrm{mol}$ glycyl-L-proline hydrolyzed $/ \mathrm{h} / \mathrm{ml}$ compared to $5 \mu \mathrm{mol} / \mathrm{h} / \mathrm{ml}$ for hemolysates of cells incubated in the absence of $\mathrm{Mn}^{++}$. Hydrolysis of glycyl-L-proline by intact erythrocytes is reduced by the slow rate of iminodipeptide transport into the cell; however, intact cells hydrolyzed this substrate at a rate 10-20 times faster after preincubation with $\mathbf{M n C l}_{2}$. After exogenous $\mathrm{MnCl}_{2}$ is removed from the storage buffer, high levels of erythrocyte prolidase activity persist for at least 13 days. The kinetic parameters for intact activated erythrocytecatalyzed hydrolysis of glycyl-L-proline have been estimated. These values predict that donor erythrocytes, activated with $\mathrm{Mn}^{++}$before transfusion could play a significant role in the recovery of proline from dietary sources of iminodipeptides in patients with prolidase deficiency. (Pediatr Res 24:709-712, 1988)
\end{abstract}

\section{Abbreviations}

glypro, glycyl-L-proline

$\mathrm{Km}$, Michaelis constant

TBS, Tris-buffered saline

TCA, trichloroacetic acid

TRIS, tris (hydroxymethyl) aminomethane

Vmax, maximal velocity

Prolidase deficiency is a rare autosomal recessively inherited inborn error of metabolism. Prolidase (E.C. 3.4.13.9) is a dipeptidase with absolute specificity for dipeptides with carboxy terminal imino acids. The gene locus (PEPD) has been mapped to chromosome 19.

The clinical findings in prolidase deficiency are variable, but patients usually present with skin ulcers and recurrent infections and, frequently, with mild mental retardation. A characteristic

Received April 15, 1988; accepted August 10, 1988.

Correspondence Peter Hechtman, de Belle Lab for Biochemical Genetics, Montreal Children's Hospital, 2300 Tupper St., Montreal, Quebec, Canada H3H 1P3.

Contribution 88020 of the McGill University-Montreal Children's Hospital Research Institute.

Supported by the Medical Research Council of Canada through a grant to its Human Genetics Research Group. dysmorphology has also been described. Biochemically, the condition is marked by massive iminodipeptiduria. The most abundant of these urinary iminodipeptides is glycylproline (1). Some asymptomatic individuals have been detected by neonatal screening programs (2), and by investigation of sibs of clinically affected probands $(3,4)$.

Although the cause of the pathology is not known, it has been proposed that one or more of the symptoms may reflect a tissue deficiency of L-proline, which is not reclaimed in the absence of prolidase. Excretion of this amino acid, in bound form, has been estimated to vary between $20-30 \mathrm{mmol} /$ day in some patients (5). Although failure to recover the proline from iminodipeptides may play a role in the pathogenesis of prolidase deficiency it cannot account for all the symptomology. Numerous reports ( 3 , 6-8) document the failure of oral administration of L-proline to relieve the dermatological lesions associated with prolidase deficiency.

Regardless of the pathologic mechanisms, many workers have considered the desirability of a mode of therapy for prolidase deficiency using enzyme replacement. Two groups $(9,10)$ attempted transfusion of patients deficient in prolidase with normal matched erythrocytes. In both cases no effect on iminodipeptiduria or upon clinical symptoms was seen despite the fact that in one case (9), erythrocyte prolidase activity reached $35 \%$ of normal levels in the patient's circulation.

Despite disappointing initial results, enzyme replacement via blood transfusion remains an appealing prospect. The circulation is uniquely accessible to enzyme replacement vehicles and furthermore this compartment represents the final opportunity to reclaim the amino acids in iminodipeptides before they are cleared by the kidney. We have therefore investigated the regulation of erythrocyte prolidase activity in hemolysates and intact cells. Our results indicate that brief exposure of intact erythrocytes to low concentrations of Mn significantly activates intracellular prolidase without causing hemolysis. We discuss the implications of these findings for enzyme replacement therapy in prolidase deficiency.

\section{MATERIALS AND METHODS}

Preparation of blood cells and hemolysates. For most experiments expired human erythrocytes were obtained from the hospital blood bank. These preparations were 35 days old and had been stored in $63 \mathrm{ml}$ of citrate-phosphate-dextrose-adenine at $4^{\circ}$ C. For some experiments fresh blood was obtained by venipuncture of laboratory volunteers and rapid transfer into heparinized tubes.

Cells were separated from plasma or from anticoagulant by centrifugation at $2100 \mathrm{rpm}$ at $22^{\circ} \mathrm{C}$ for $10 \mathrm{~min}$. The cells were washed by resuspension in $10 \mathrm{mM}$ Tris- $\mathrm{HCl} \mathrm{pH} \mathrm{7.4-0.9 \%} \mathrm{TBS}$ and recentrifugation until all soluble hemoglobin was removed (usually three to four washes). 
Hemolysates were prepared by dilution of washed erythrocytes with $1 \mathrm{vol}$ of $10 \mathrm{mM}$ Tris- $\mathrm{HCl} \mathrm{pH} \mathrm{7.4.} \mathrm{The} \mathrm{resuspended} \mathrm{eryth-}$ rocytes were rapidly frozen in dry ice-ethanol or overnight at $-20^{\circ} \mathrm{C}$ and thawed at $37^{\circ} \mathrm{C}$.

For activation of prolidase in intact erythrocytes, the washed cells were suspended in 1 volume of TBS containing $0.5 \%$ glucose, $0.5 \%$ human serum albumin (Connaught Labs, Toronto, Canada), and 1/100 volume of Eagle's antibiotic preparation and incubated without shaking overnight at $37^{\circ} \mathrm{C}$. Each activation was performed in parallel with one sample of the washed erythrocytes containing $0.5 \mathrm{mM} \mathrm{MnCl} 2$ in the above buffer and an identical sample incubated in Mn-free buffer. After incubation, the cell suspension was centrifuged to remove $\mathrm{Mn}$ and any $\mathrm{Hb}$ released. Cells were then resuspended in TBS.

Activation of prolidase in hemolysates was achieved by overnight incubation at $37^{\circ} \mathrm{C}$ in the presence of $1 \mathrm{mM} \mathrm{MnCl}_{2}$.

Measurement of prolidase activity in hemolysates and intact cells. Determination of prolidase with glycyl-L-proline was performed using conditions of Myara et al. (11) except that $\mathrm{MnCl}_{2}$ was not added to reaction mixtures unless indicated. The distinction is made between "holoenzyme" meaning the active form of prolidase which is detectable without the requirement for preincubation with $\mathrm{Mn}^{++}$and "apoenzyme" referring to the inactive form of prolidase which requires preincubation with $\mathrm{Mn}^{++}$for formation of a catalytically active species.

Glycyl-L-proline was purchased from Sigma (St. Louis, MO). Incubations with intact cells were performed in $10 \mathrm{vol}$ of TBS $\mathrm{pH} 7.4$ without shaking. Reactions were terminated by centrifugal separation of cells under conditions indicated above. A portion of the supernatant was retained for monitoring hemolysis which occurred during the reaction. The remainder of the supernatant was treated with TCA according to Myara et al. (11) and released proline was quantitated spectrophotometrically. When prolidase activity was assayed in hemolysates, the TCA-terminated reaction mixtures were centrifuged prior to color development in order to reduce the contribution of hemoglobin to absorbance at $515 \mathrm{~nm}$.

Other assay procedures. Hemolysis occurring during incubation of intact cells with substrate was estimated by measurement of absorbance at $405 \mathrm{~nm}$ of supernatants obtained after centrifugation of reaction mixtures.

Protein was determined by the Biorad Procedure (12). $\mathrm{Mn}^{++}$ concentration was determined by atomic absorption spectrometry. Glycyl-L-proline was determined by amino acid analysis using a Dionex D-500 analyzer. This dipeptide elutes at a position identical to the internal standard norleucine but does not have the same retention time as any amino acid found in the serum.

\section{RESULTS}

Activation of hemolysate prolidase by manganese ions. The requirement of prolidase for manganese ions is well established; however, in procedures currently in use for prolidase estimation (11) $\mathrm{Mn}^{++}$is routinely included in incubations containing the substrate as well as in a preincubation step. It is not known if $\mathrm{Mn}^{++}$functions as a cosubstrate in the catalytic reaction or as an inducer (or stabilizer) of the catalytically active state of the enzyme. We therefore undertook to determine 1) whether erythrocytes contain prolidase in the apoenzyme form, 2) and if so, whether aprolidase present in hemolysates can be activated by exposure to $\mathrm{Mn}$ ions in a preincubation step or whether enzyme activity also depended on inclusion of the divalent cation in a substrate-containing reaction mixture as well as in a preincubation step.

The results presented in Table 1 indicate that most of the prolidase in hemolysates is in the catalytically inactive form. The data in Table 1 also strongly supports the hypothesis that $\mathrm{Mn}^{++}$ ions interact with an apoprolidase to produce a stable, catalytically active structure with stoichiometric and irreversibly bound metal ions but that "free" Mn is not itself directly involved in the catalytic reaction. Overnight incubation of hemolysate in 1 $\mathrm{mM} \mathrm{MnCl} 2$ results in a $15-30$-fold enhancement of prolidase

Table 1. Activation of erythrocyte prolidase by manganous ions

\begin{tabular}{cc}
$\begin{array}{c}\text { Reaction mixture } \\
\text { contains* } \\
\mu \text { mol gly-pro } \\
\text { Preincubation }\end{array}$ & $\begin{array}{c}\text { hydrolyzed } / \mathrm{h} / \mathrm{ml} \text { cells of } \\
-\mathrm{MnCl}_{2}+\mathrm{MnCl}_{2}\end{array}$ \\
\hline
\end{tabular}

\section{Hemolysate}

$16 \mathrm{~h}-\mathrm{MnCl}_{2}$

$16 \mathrm{~h}+\mathrm{MnCl}_{2}$

5.0

159

Hemolysate (fresh blood) $\dagger$

$16 \mathrm{~h}-\mathrm{MnCl}_{2}$

$16 \mathrm{~h}+\mathrm{MnCl}_{2}$

Intact cells?

$16 \mathrm{~h}-\mathrm{MnCl}_{2}$

$16 \mathrm{~h}+\mathrm{MnCl}_{2}$

Activated, partially purified enzyme

Control enzyme

$16 \mathrm{~h}-\mathrm{MnCl}_{2}$

$16 \mathrm{~h}+\mathrm{MnCl}_{2}$

Dialyzed, preincubated

$16 \mathrm{~h}-\mathrm{MnCl}_{2}$

$16 \mathrm{~h}+\mathrm{MnCl}_{2}$

\begin{tabular}{lc}
$\begin{array}{c}\text { Intracellular } \mathrm{Mn} \text { con- } \\
\text { centration } \mu \mathrm{g} / \mathrm{ml} \\
\text { cells }\end{array}$ \\
$\begin{array}{l}\text { Intact cells } \\
16 \mathrm{~h}-\mathrm{MnCl}_{2}\end{array}$ \\
$16 \mathrm{~h}+\mathrm{MnCl}_{2}$ & 0.014 \\
\hline * Substrate concentration, $50 \mathrm{mM}$. & 2.04 \\
$\dagger$ All other preparations use expired blood bank samples. \\
$\begin{array}{l}\ddagger \text { Substrate concentration, } 1 \mathrm{mM} \text {. } \\
\S \text { Hemolysate activated by overnight incubation with } 1 \mathrm{mM} \mathrm{MnCl}_{2}\end{array}$ \\
and partially purified by DEAE cellulose according to Endo et al. $(7)$.
\end{tabular}

specific activity. Thus, in crude hemolysates, maximal specific activity depends on the prolonged presence of $\mathrm{Mn}^{++}$in preincubation mixtures rather than its short-term presence in substrate containing reaction mixtures. This conclusion is supported by data obtained with activated, partially purified enzyme shown in the lower part of Table 1. Once activated before ion exchange chromatography on DEAE cellulose (9), neither another overnight incubation with $\mathrm{MnCl}_{2}$ nor the presence of $\mathrm{Mn}^{++}$in the reaction mixture further enhanced the specific activity of the enzyme.

Dialysis of the partially purified prolidase preparation resulted in only a modest decrease in enzyme activity, all of which was restored upon overnight preincubation. These results point to a high affinity of binding between $\mathrm{Mn}^{++}$and prolidase.

These data support the following tentative conclusions that are relevant to the development of a blood transfusion based strategy for the treatment of prolidase deficiency: 1) donor erythrocytes contain primarily inactive prolidase and are therefore unlikely to be effective in reducing iminodipeptiduria; 2) if prolidase in donor erythrocytes can be "activated" before transfusion by incubation of cells with $\mathrm{Mn}^{++}$they would constitute a greatly enhanced source of active enzyme; 3 ) covalent binding of $\mathrm{Mn}^{++}$to prolidase implies that excess unbound $\mathrm{Mn}^{++}$could be removed from Mn-treated erythrocytes without reducing enzyme activity. The importance of this last point is that it would permit putative "activated" erythrocytes to be transfused into patients the same time infusing large amounts of $\mathrm{Mn}^{++}$ions, which have been shown in animal studies to be neurotoxic (13)

Activation of erythrocyte prolidase and hydrolysis of glycyl-Lproline by intact cell. Activation of erythrocyte prolidase by extracellular $\mathrm{Mn}^{++}$was measured after hemolysis of cells which had been incubated with and without manganese for $16 \mathrm{~h}$ at $37^{\circ}$ C. The results, shown in Table 1 , indicate that $\mathrm{Mn}$ can enter the 
red cell and that hemolysates prepared from cells which had been incubated overnight in $\mathrm{MnCl}_{2}$-containing buffer have approximately $15-$ to 30 -fold more prolidase activity than erythrocytes subjected to incubations in the absence of $\mathrm{Mn}$. Activation of prolidase in freshly prepared erythrocytes occurs to the same extent as in the expired blood samples.

Preincubation with $\mathrm{Mn}^{++}$is also associated with an increase in the intracellular concentration of the metal of approximately 150 -fold. The concentration of $\mathrm{Mn}^{++}$found in hemolysates of cells preincubated in the absence of $\mathrm{MnCl}_{2}$ (Table 1) was virtually identical to the levels found for control erythrocytes using neutron activation analysis (14). The erythrocyte, once exposed to $\mathrm{Mn}^{++}$, is able to activate prolidase, to retain the enzyme in the active form after excess $\mathrm{Mn}^{++}$is removed from the buffer by centrifugation and to internalize glycyl-L-proline when it is present at low $(1 \mathrm{mM})$ concentration. The velocity of glycyl-Lproline hydrolysis in intact cells is only $1 / 80$ that of the hemolysate (Table 1). It is, therefore, apparent that the kinetic parameters of iminodipeptide hydrolysis by activated erythrocytes will reflect those of the rate-limiting step, membrane transport, rather than those of the enzyme.

Kinetics of glycyl-L-proline hydrolysis. Figure 1 shows a comparison of Lineweaver-Burke plots for hydrolysis of glycyl-Lproline by intact cells that had been preincubated overnight with and without $\mathrm{Mn}$. A corresponding plot for activated hemolysate prolidase is also shown.

The kinetic parameters Vmax and $\mathrm{Km}$ obtained from these graphs are summarized in Table 2 along with comparable values obtained by other investigators. In all cases velocities for glycyl-

L-proline hydrolysis by intact cells are considerably lower than velocities for hemolysates. Both King and Kuchel (15) and Endo et al. (9) used erythrocytes that had not been exposed to $\mathrm{Mn}^{++}$. The difference between the Vmax for unactivated erythrocytes noted by us and by King and Kuchel (15) may be due to the use of different procedures. King and Kuchel (15) used nucleomagnetic resonance to estimate both intra- and extracellular proline, whereas we and Endo et al. (9) used Chinard reagent to measure extracellular proline only. Using the same procedures as Endo, our estimate of the $V_{\max }$ for activated erythrocytes is 28 -fold higher than for our unactivated erythrocytes and 10-fold higher than King and Kuchel's value for $\mathrm{V}_{\max }$ in unactivated cells.

The capacity of activated erythrocyte for iminodipeptide hydrolysis. The ability of activated erythrocytes to contribute to reclamation of proline through hydrolysis of plasma iminodipeptides depends on three factors. These are the kinetic parameters of the coupled iminodipeptide transport-prolidase system, the number of activated erythrocytes and the plasma iminodipeptide concentration.

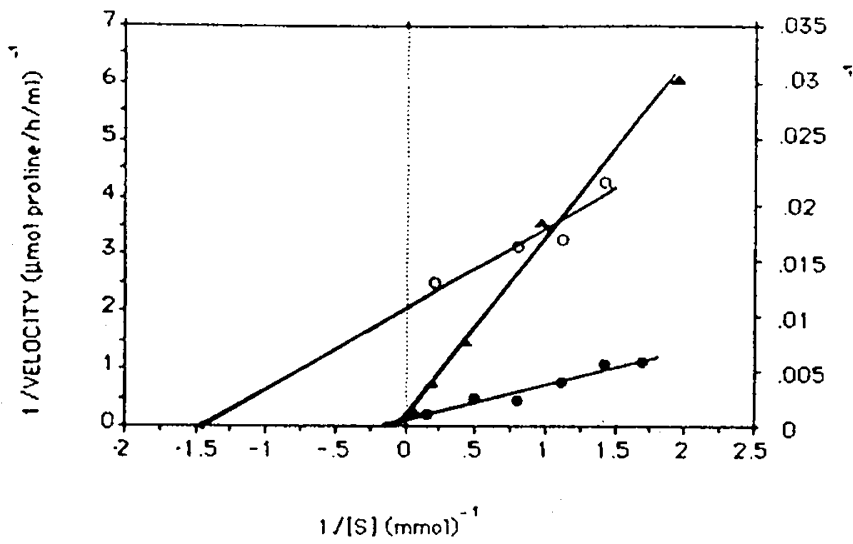

Fig. 1. Kinetics of hydrolysis of glycyl-L-proline. Open circles, intact cells preincubated overnight without $\mathrm{MnCl}_{2}$; closed circles, intact cells preincubated overnight with $\mathrm{MnCl}_{2}$; triangles, hemolysate prepared from cells preincubated with $\mathrm{MnCl}_{2}$. Velocity values for hydrolysis by intact cells refer to scale on the left, velocity values for hemolysate refer to scale on the right.
Table 2. Kinetic parameters for glycyl-L-proline hydrolysis by intact cells and hemolysates

\begin{tabular}{ccc}
\hline & $\mathrm{Km}(\mathrm{mM})$ & $\begin{array}{c}\mathrm{V}_{\max } \\
(\mu \mathrm{mol} / \mathrm{ml} \mathrm{RBC} / \mathrm{h})\end{array}$ \\
\hline $\mathrm{Mn}^{++}$Activated cells & 6.67 & 10 \\
Unactivated cells & 1.0 & 0.36 \\
Activated hemolysate & 10.1 & 568 \\
King and Kuchel (10) & & \\
Unactivated cells & 4.7 & 1.0 \\
Activated hemolysate & 14.1 & 130 \\
Endo et al. $(7)$ & & $0.165^{*}$ \\
Unactivated cells & & $147^{*}$ \\
Activated hemolysates & & \\
\hline
\end{tabular}

* Velocity at $10 \mathrm{mM}$ glycyl-L-proline.

Table 3. Capacity of activated erythrocytes for catabolism of iminodipeptide

\begin{tabular}{ccccc}
\hline $\begin{array}{c}\text { Gly-pro } \\
\text { concentration: } \\
\text { serum }\end{array}$ & \multicolumn{2}{c}{$\begin{array}{c}\text { Velocity mmol } \\
\text { proline/U RBC/ } \\
24 \mathrm{~h}^{*}\end{array}$} & $\begin{array}{c}\text { \% of iminodipeptide } \\
\text { output hydrolyzed } \dagger / \\
\text { unit RBC }\end{array}$ \\
\hline $\mathrm{mM}$ & $+\ddagger$ & $-\S$ & + & - \\
0.01 & 0.108 & 0.076 & 0.43 & 0.10 \\
0.025 & 0.266 & 0.063 & 1.06 & 0.25 \\
0.1 & 1.08 & 0.238 & 4.32 & 0.95 \\
0.25 & 2.59 & 0.52 & 10.4 & 2.08 \\
1.0 & 9.36 & 1.30 & 37.4 & 5.2 \\
\hline
\end{tabular}

$* 1 \mathrm{U} \mathrm{RBC}=300 \mathrm{ml}$.

$\dagger 100 \%$ iminodipeptide $=25 \mathrm{mmol} /$ day.

$\$$ Cells activated with $\mathrm{Mn}^{++}$.

$\S$ Unactivated cells.

Table 3 shows velocity values that correspond to various hypothetical plasma glycyl-L-proline concentrations in the "physiologic" range. Velocities are calculated as $\mathrm{mmol} / 24 \mathrm{~h}$ to facilitate comparison with the magnitude of daily iminodipeptide excretion by patients with prolidase deficiency. Taking $25 \mathrm{mmol}$ of iminodipeptide excreted per day as the average value reported for patients with this phenotype, the velocities calculated have also been transformed into "percent of daily iminodipeptide output hydrolyzed per transfusion unit of erythrocytes."

The data in Table 3 indicate that the effect of manganese activation is greater at higher substrate concentrations. If, for example the concentration of iminodipeptides in plasma were to reach $1 \mathrm{mM}$, complete recovery of proline could occur due to the activity of erythrocyte prolidase present in less than $3 \mathrm{U}$ of activated donor erythrocytes. We consider the relationship between plasma concentrations of iminodipeptide and the source of those substrates.

The stability of activated erythrocyte prolidase. Prolidase activity in activated erythrocytes was normally measured within $2 \mathrm{~h}$ of placing the activated cells into a manganese free buffer. If enzyme replacement by infusion of activated erythrocytes is to be considered as a potential therapeutic tool it is necessary to demonstrate long-term stability of the holoenzyme form of prolidase within the cells after removal of extracellular $\mathrm{MnCl}_{2}$. $\mathrm{Hy}-$ drolysis of glycyl-L-proline in activated cells remains at least 6fold higher than in unactivated cells during the 13 days that the cells were stored under sterile conditions at room temperature in the absence of $\mathrm{Mn}^{++}$. Specific activities of activated erythrocytes were between 1.9 and $2.4 \mu \mathrm{mol} / \mathrm{ml} / \mathrm{h}$ during this interval. Longer periods of storage resulted in virtually complete hemolysis of both activated and unactivated cells.

\section{DISCUSSION}

The demonstration that prolidase occurs in an inactive form within human erythrocytes suggests a reason why attempts to cure iminodipeptiduria by infusion of normal erythrocytes were unsuccessful. In a transfused subject, iminodipeptide substrates would encounter a membrane-enclosed apoenzyme rather than 
the solubilized activated holoenzyme detected by the Myara procedure (11). The use of $\mathrm{Mn}$ to activate erythrocyte prolidase has been the starting point for these investigations. Although $\mathrm{Mn}^{++}$activation of prolidase in tissue extracts has been demonstrated using a variety of enzyme sources, it has never been shown whether prolidase present within intact cells can be activated by addition of $\mathrm{Mn}^{++}$to the extracellular fluid without compromising the integrity of the cells. Previous studies showed that the metal ion is covalently bound to a sulfur atom that is required for catalytic activity (16). Recent work indicates that preincubation with $\mathrm{Mn}$ stabilizes fibroblast prolidase against thermal inactivation (17). Our results indicated that 1 ) the membrane is permeable to $\mathrm{Mn}^{++}$; 2) $\mathrm{Mn}^{++}$entering the cell is not completely sequestered by either membrane phospholipids or by other proteins; and 3) prolidase in situ is in a state in which its active site is accessible to $\mathrm{Mn}$ ions.

The prospects for successful treatment of prolidase deficiency using transfusion of affected persons with manganese activated erythrocytes depends upon the capacity of the donor erythrocytes to hydrolyze iminodipeptides in relation to the amounts of these substrates to which these cells would be exposed. The recovery of free imino acids would be slower at lower plasma iminodipeptide concentrations.

Scriver (18) found a value of $10 \mu \mathrm{M}$ for glycyl-L-proline in patients with bone disease and Freij et al. (19) reported values of $24 \mu \mathrm{m}$ for glycyl-L-proline in prolidase-deficient patients. Other workers reported that this iminodipeptide was completely absent from plasma of prolidase-deficient patients. Values for plasma iminodipeptide concentrations are scarce in the patients as well as normal subjects. These reports of low or absent iminodipeptide in plasma are based on fasting conditions. Under these conditions the major source of urinary iminodipeptides in prolidase deficient subjects is expected to be the turnover of collagen. Based on hydroxyproline excretion in patients, the turnover of collagen has been estimated to range from $1-6 \mathrm{~g} /$ day (5).

Collagen turnover cannot be the only, or even the major, source of iminodipeptides in urine. The ratio of proline to hydroxyproline residues in collagen has been estimated at 1.11.6, however iminodipeptides containing proline are frequently found in $5-$ to 10 -fold excess compared to hydroxyproline containing dipeptides in the urine of prolidase-deficient patients. These findings suggest that proteins other than collagen are precursors of urinary iminodipeptides.

A role for dietary protein as the source of the iminodipeptide in urine is also indicated by gelatin loading studies performed on human subjects (20). These studies suggest that plasma levels of iminodipeptide increase rapidly after ingestion of a protein meal. In prolidase deficient subjects these substrates enter the blood via an intestinal dipeptide transport system that is genetically and kinetically distinct from amino acid transporters (21). Such transient increases in plasma iminodipeptide concentrations have been documented in human studies, in which plasma peptide-bound hydroxyproline reaches $0.25-0.35 \mathrm{mM}$ within three hours of a gelatin meal (22) and in rats, in which glycylproline reaches $0.6 \mathrm{mM}$ in mesenteric plasma within 10 min of an intraluminal injection of this substrate (23).

The principal source of urinary iminodipeptides in prolidasedeficient individuals is therefore not likely to be the steady leakage of human collagen breakdown products into plasma but the intermittent absorption of peptides derived from dietary protein. High plasma dipeptide levels attained through this process suggest a potentially significant role for activated erythrocyte prolidase in the recovery of large amounts of proline from plasma iminodipeptides.

Our results provide a basis for attempting a fresh approach to enzyme replacement therapy in prolidase deficiency. They show that inactive, or apo-prolidase in human erythrocytes is responsive to exogenous $\mathrm{Mn}$ and cells in which the active or holoenzyme form of prolidase has been formed retain high levels of enzymatic activity for at least $2 \mathrm{wk}$. In a test tube such cells can convert glycyl-L-proline to free amino acids at a rate 20 times more than cells which have not been exposed to Mn.

Two important questions remain: 1) does the manganese activation procedure compromise the longevity or the functional integrity of the erythrocyte? and 2) does transfusion of patients with Mn-loaded erythrocytes introduce potentially toxic amounts of metal into the body? If these questions can be answered in the negative by animal studies, then we suggest that the manganese-activated erythrocyte system be considered as a serious candidate for clinical trial in cases of prolidase deficiency.

Acknowledgments. The authors thank Dr. Yukio Tanaka of the Biochemistry Department of the Montreal Children's Hospital for determination of manganese content of biologic preparations. We thank Mrs. Louise Smith-Jones for technical assistance and Ms. Lynne Prevost for typing the manuscript.

\section{REFERENCES}

1. Myara I, Charpentier C, Lemonnier A 1984 Minireview: Prolidase and prolidase deficiency. Life Sci 34:1985-1988

2. Naughten FR, Proctor SP, Levy HL, Coulombe JT, Ampola MG 1984 Congenital Expression of Prolidase Defect in Prolidase Deficiency. Pediatr Res $18: 259-261$

3. Isemura M, Hanyu T, Gejyu F, Nakazawa R, Igarashi R, Matsuo S, Ikeda K, Sato Y 1979 Prolidase deficiency with imidodipeptiduria, a familial case with and without clinical symptoms. Clin Chim Acta 93:401-407

4. Umemura S 1978 Studies on a patient with iminodipeptiduria. II lack of prolidase activity in blood cells. Physiol Chem Phys 10:279-283

5. Scriver CR, Smith RJ, Phang JM 1983 Disorders of proline and hydroxyproline metabolism. In: Stanbury JB, Wyngaarden JB, Fredrickson DS, Goldstein JL, Brown MS (eds) The Metabolic Basis of Inherited Disease. McGrawHill, New York, pp 360-381

6. Sheffield LJ, Schlesinger P, Faull K, Halpern BJ, Schier GM, Cotton RGH, Hammond J, Danks DM 1977 Iminopeptiduria, skin ulcerations and edema in a boy with prolidase deficiency. J Pediatr 91:578-583

7. Pedersen PS, Christensen E, Brandt NJ 1983 Case report: Prolidase deficiency. Acta Paediatr Scand 72:785-788

8. Ogata A, Tanaka S, Tomoda T, Murayana E, Endo F, Kikuchi I 1981 Autosomal recessive prolidase deficiency. Arch Dermatol 117:689-694

9. Endo F, Matsuda I, Ogata A, Tanaka S 1982 Human erythrocyte prolidase and prolidase deficiency. Pediatr Res 16:227-231

10. Isemura $M$, Hanyu $T$, Ono $T$, Icarashi $R$, Sato $Y$, Gejyo F, Wakazawa $R$, Miyakawa T, Takagi T, Kuboki Y, Saski S 1981 Studies on prolidase deficiency with a possible defect in collagen metabolism. Tohoku J Exp Med $134: 21-28$

11. Myara I, Charpentier C, Lemonnier A 1982 Optimal Conditions for prolidase assay by proline colorimetric determination: application to iminodipeptiduria. Clin Chim Acta 125:193-205

12. Bradford MM $1976 \mathrm{~A}$ rapid and sensitive method for the quantitation of microgram quantities of protein utilizing the principal of protein dye binding. Anal Biochem 72:248-254

13. Shuka GS, Singhal RL 1984 The present states of biological effects of toxic metals in the environment: lead, cadmium and manganese. Can J Physiol Pharmacol 62: 1015-1031

14. Lombeck I, Wendel V, Versieck J, van Ballenberghe L, Brimer HJ, Duran R, Wadman $S 1986$ Increased manganese content and reduced arginase activity in erythrocytes of a patient with prolidase deficiency (iminodipeptiduria) Eur J Pediatr 144:571-573

15. King GF, Kuchel PW 1984 A proton n.m.r. study of iminodipeptide transport and hydrolysis in the human erythrocyte. Biochem J 220:553-560

16. Smith EL, Davis NC, Adam E, Spackman DH 1954 The Specificity and mode of action of two metal dipeptidases. In: McElroy WD (ed) Mechanism of Enzyme Action. Johns Hopkins Press, Baltimore, pp 291-305

17. Priestman DA, Butterworth J 1984 Prolidase Deficiency: Characteristics of human skin fibroblast prolidase using colorimetric and fluorimetric assays. Clin Chim Acta 142:263-271

18. Scriver CR 1964 Glycylproline in the urine of humans with bone disease. Can J Physiol Pharmacol 42:357-364

19. Freij BJ, Levy HL, Dudin G, Mutasim D, Deeb M, Der Kaloustian VM 1984 Clinical and biochemical characteristics of prolidase deficiency in siblings. Am J Med Genet 19:561-571

20. Powell GF, Maniscalco RM 1976 Bound hydroxyproline excretion following gelatin loading in prolidase deficiency. Metabolism 25:503-508

21. Rubino A, Field M, Schwachman H 1971 Intestinal transport of amino acid residues of dipeptides: I Influx of the glycine residue of glycyl-L-proline across the mucosal border. J Biol Chem 246:3542-3548

22. Bronstein HP, Haeffner LJ, Kowlessor OD 1966 The significance of gelatin tolerance in malabsorptive states. Gastroenterology 50:621-630

23. Boullin DJ, Crampton RF, Heading CE, Pelling D 1973 Intestinal absorption of dipeptides containing glycine, phenyalalanine, proline, $\beta$-alanine or histidine in the rat. Clin Sci Mol Med 45:849-858 